\title{
Application of 10\% Ascorbic Acid Improves Resin Shear Bond Stregth in Bleached Dentin
}

\author{
Kamizar $^{1}$, Endang Suprastiwi', Yusi Heptorina² \\ ${ }^{1}$ Department of Conservative Dentistry, Faculty of Dentistry, Universitas Indonesia, Jakarta 10430, Indonesia \\ ${ }^{2}$ Conservative Dentistry Residency Program, Faculty of Dentistry, Universitas Indonesia, Jakarta 10430, Indonesia \\ Correspondencee-mail: kamizar_kz@yahoo.com
}

\begin{abstract}
Restoration of the teeth immediately after bleaching with $\mathrm{H}_{2} \mathrm{O}_{2} 35 \%$ is contraindicated due to the remnants of free radical that will stay inside dentin for 2-3 weeks which will compromise the adhesiveness of composite resin. Objective: The aim of this study was to evaluate the influence of $10 \%$ ascorbic acid on shear bond strength of composite placed on bleached dentin. Methods: Twenty seven samples were divided equally into three groups. Group 1: dentin was etched with $35 \%$ phosphoric acid; Group 2: dentin was bleached with $35 \% \mathrm{H}_{2} \mathrm{O}_{2}$ followed by etching with $35 \%$ phosphoric acid; Group 3: dentin was bleached with $35 \% \mathrm{H}_{2} \mathrm{O}_{2}$, followed by application of $10 \%$ ascorbic acid and etched with $35 \%$ phosphoric acid. All samples were then stored at $37^{\circ} \mathrm{C}$ for 24 hours. The Universal Testing Machine was used to measure shear bond strength and the results were analyzed with Kruskal Wallis and Mann Whitney test. Results: After nine independent experiments, $10 \%$ ascorbic acid application on bleached dentin resulted in highest increased in bond stregth $(56.04 \pm 11.06 \mathrm{MPa})$ compared to Group $2(29.09 \pm 7.63 \mathrm{MPa})$ and Group $1(25.55 \pm 2.22 \mathrm{MPa})$ and the difference was statistically significant $(p<0.05)$. Conclusion: Application of $10 \%$ ascorbic acid to the bleached dentin improved the shear bond strength of resin composite.
\end{abstract}

\begin{abstract}
ABSTRAK
Aplikasi asam askorbat $10 \%$ meningkatkan shear bond strength resin pada dentin pasca pemutihan gigi. Gigi pasca pemutihan gigi interna merupakan kontra indikasi untuk segera dilakukan restorasi, karena adanya radikal bebas yang masih tertinggal di dalam dentin selama 2-3 minggu dan dapat menggangu adaptasi bahan restorasi resin komposit. Tujuan: Menganalisis pengaruh aplikasi asam askorbat 10\% terhadap shear bond strength resin komposit pada dentin pasca pemutihan gigi interna dengan gel $\mathrm{H}_{2} \mathrm{O}_{2} 35 \%$. Metode: Dua puluh tujuh sampel gigi dibagi menjadi tiga kelompok. Grup 1: Dentin dietsa dengan asam fosfat 35\%; Grup 2: Dentin dilakukan pemutihan gigi interna dengan gel $\mathrm{H}_{2} \mathrm{O}_{2} 35 \%$, dietsa dengan asam fosfat 35\%; Grup 3: Dentin dilakukan pemutihan gigi interna dengan gel $\mathrm{H}_{2} \mathrm{O}_{2} 35 \%$, aplikasi asam askorbat $10 \%$ selama 10 menit, dan dietsa dengan asam fosfat $35 \%$. Semua gigi percobaan di inkubasi pada $37^{\circ} \mathrm{C}$ selama 24 jam. Uji shear bond strength dilakukan dengan alat Universal Testing Machine. Data yang diperoleh dianalisis secara statistik dengan tes Kruskal Wallis dan Mann Whitney. Hasil: Analisis sembilan sampel dari masing-masing grup menunjukkan bahwa peningkatan shear bond strength yang paling banyak terjadi pada Grup $3(56,04 \pm 11,06 \mathrm{MPa})$ dibanding dengan Grup $2(29,09 \pm 7,63 \mathrm{MPa})$ dan Grup $1(25,55 \pm 2,22 \mathrm{MPa})$ dan perbedaannya bermakna secara statistik $(p<0,05)$. Simpulan: Aplikasi asam askorbat $10 \%$ pada dentin pasca pemutihan gigi interna dengan gel $\mathrm{H}_{2} \mathrm{O}_{2} 35 \%$ dapat meningkatkan shear bond strength resin komposit.
\end{abstract}

Key words: $10 \%$ ascorbic acid, dental bleaching, dentin, shear bond strength 


\section{INTRODUCTION}

Dentin is a calcified tissue and consists of tiny tubules or tubes. It is the second layer of a tooth and normally covered by enamel. Dentin covers the pulp tissue and constitutes the largest portion the tooth's structure. Dentin is denser and harder than bone and it's color may range anywhere from grey to black but typically is pale yellow. This yellow hue is generally what is seen penetrating through the tooth's enamel. Adhesion is a complex physical and chemical mechanism that allows the attachment of one substance to another. Good adhesion to dentin is one of the ideal properties of resin cement. Shear bond strength testing is one of the best measures of the adhesion. ${ }^{1}$

Hydrogen peroxide $\left(\mathrm{H}_{2} \mathrm{O}_{2}\right)$ is an active ingredient of dental bleaching agent. Thirty five percent of $\mathrm{H}_{2} \mathrm{O}_{2}$ has the highest bleaching effect and is available in gel form which is the safest formulation. ${ }^{2}$ It is a strong oxidizer through the formation of free radicals. ${ }^{3-5}$ Free radicals are electrons which do not have partner, unstable, and highly reactive.$^{5-9}$ Free radicals or reactive molecules produced by $\mathrm{H}_{2} \mathrm{O}_{2}$ will break the long-chained chromophore molecules, the cause of tooth discoloration, into smaller molecules with brighter colors. ${ }^{4,5}$

After bleaching process, the free radical remnants will stay inside the tooth especially on dentin within 2-3 weeks. ${ }^{10-12}$ These free radicals will compromise the adhesivity of composite resin because will distract the polymerization of composite resin due to a premature termination. ${ }^{13,14}$ It inhibits the binding process of the tooth structure and composite resin. Although, there was not much investigation on the bond strength of composite resin to the bleached dentin, almost all research, confirmed poor bond strength following bleaching treatment. It is believed that bond strength of composite resin to dentin is related to composite resin bond strength to enamel after bleaching process. ${ }^{11}$ Almost all literatures which used $25-35 \% \mathrm{H}_{2} \mathrm{O}_{2}$ showed neither shear bond strength nor tensile bond strength decreased on all composite resin type which are filled directly after bleaching procedure.

Antioxidant is a substance which has ability to neutralize free radicals after bleaching process. Ascorbic acid (vitamin $\mathrm{C}$ ) is an antioxidant and it will react with superoxyde $\left(\mathrm{O}_{2} \times\right)$, hydrogen peroxyde $\left(\mathrm{H}_{2} \mathrm{O}_{2}\right)$, hydroxyl ion $(\mathrm{OH} \times) .{ }^{14,15}$ The purpose of this study was to evaluate the effect of $10 \%$ ascorbic acid application to the shear bond strength of composite resin after bleaching with $35 \% \mathrm{H}_{2} \mathrm{O}_{2}$.

\section{METHODS}

Twenty seven dentin samples from maxillary premolars were soaked in saline solution until use. Tooth crowns were sliced $2 \mathrm{~mm}$ horizontally below the cervical area, then cut into two pieces in bucco-palatal direction. Those halves part were fixed on $20 \mathrm{~mm}$ diameters resin acrylic mould with dentin surface faced up and free from resin acrylic. The sample surfaces were ground flat using sand paper grit 800, 1200, 2000 and were polished using alumina paste until the surface was smooth and homogen.

The samples were divided equally into 3 groups. In Group 1, dentin surfaces were etched with 35\% phosphoric acid (Scotchbond-Etchant, 3M ESPE) for 15 seconds-rinsed with water and dried. Bonding agent was then applied (Adper Single Bond 2, 3M ESPE) and cured for 10 seconds. Subsequently, nanohybrid composite resin (Filtek Z350 3M ESPE), 2mm in diameter and $3 \mathrm{~mm}$ in thickness were applied to the dentin surfaces dan cured. In Group 2, 35\% $\mathrm{H}_{2} \mathrm{O}_{2}$ (Opalescence Endo Ultradent USA) were applied to dentin surfaces, covered with plastic, placed on sterile plastic box and kept in the $37^{\circ} \mathrm{C}$ incubator for 3 days. After rinsed in running water and dried, the same procedures as Group 1 were applied. In Group 3, after the the application of 35\% $\mathrm{H}_{2} \mathrm{O}_{2}$ for 3 days, dentin surfaces were rinsed with water and dried. Ten percent of ascorbic acid (Harumsari Jakarta) were applied for 10 minutes and followed by the same procedures as Group 1. All samples were kept in the $37^{\circ} \mathrm{C}$ incubator for $24 \mathrm{~h}$. Shear bond strength test for each samples was done using Universal Testing Machine with punch method..$^{17,18}$

\section{RESULTS}

After nine independent experiments, 10\% ascorbic acid application on bleached dentin resulted in highest increased in bond stregth $(56.04 \pm 11.06 \mathrm{MPa})$ compared to Group $2(29.09 \pm 7.63 \mathrm{MPa})$ and Group $1(25.55 \pm 2.22 \mathrm{MPa})$ and the difference was statistically significant $(p<0.05)$. The range of shear bond strength value of each group was described in Table 1. The result showed that $10 \%$ ascorbic acid for 10 minutes can increase shear bond strength of composite resin filling to dentin surface post internal bleaching using $35 \% \mathrm{H}_{2} \mathrm{O}_{2}$ gel approximately two times of that without ascorbic acid.

Table 1. Measurement of shear bond strength of each experimental group using universal testing machine

\begin{tabular}{cccrl}
\hline $\begin{array}{c}\text { Experimental } \\
\text { Group }\end{array}$ & $\mathrm{n}$ & $\begin{array}{c}\text { Range Value } \\
(\mathrm{MPa})\end{array}$ & $\begin{array}{c}\text { Mean } \pm \mathrm{SD} \\
(\mathrm{MPa})\end{array}$ & $p$ \\
\hline 1 & 9 & $23.23-30.25$ & $25.55 \pm 2.22$ & $0.001^{*}$ \\
2 & 9 & $10.91-36.48$ & $29.09 \pm 7.63$ & \\
3 & 9 & $41.16-73.28$ & $56.04 \pm 11.06$ & \\
\hline
\end{tabular}

* Kruskal Wallis, $p<0,005$.

Mann-Whitney test was conducted subsequently to find out the difference among each group of experiment. The result that each group had significant difference $(p<0.005)$. With that result, the hypothesis of this study 
was accepted, that the application of $10 \%$ ascorbic acid for 10 minutes increased shear bond strength of composite resin filling to dentin surface post internal bleaching using $35 \% \mathrm{H}_{2} \mathrm{O}_{2}$ gel.

\section{DISCUSSION}

Thirty five percent $\mathrm{H}_{2} \mathrm{O}_{2}$ is a strong oxidizer and commonly used as dental bleaching agent. It produces very reactive free radicals, making this substance a very powerful oxidizing agent. Ascorbic acid, a free radicals reducing agent, was reported to reverse the negative effects of the free radicals. It will restore the altered redox potential of free radicals and allow polymerization of the resin without premature termination and thus reversing the compromised bonding. ${ }^{19}$ In the present study, $10 \%$ ascorbic acid was used to reduce the free radicals on dentin treated with $35 \% \mathrm{H}_{2} \mathrm{O}_{2}$. According to Kimyai et al. (2008) $10 \%$ ascorbic acid is equally effective as the concentration of $20 \%{ }^{20}$ It was also stated that low concentration of ascorbic acid could react with hydroxyl ion into ascorbil which was less reactive while high concentration do not react. ${ }^{15}$ It needs 10 minutes contact of ascorbic acid on tooth surface after bleaching with natrium hypoclorite and $\mathrm{RC}$-Prep to remove the free radicals effect. ${ }^{20}$

Our study confirmed that application of $10 \%$ ascorbic acid significantly improved shear bond strength is in accordance with the study conducted previous research. ${ }^{12}$ There was a significant difference of shear bond strength among the three groups. Group 3 showed the highest shear bond. It is hypothesized that the difference in bond strength is realted to the free radicals ability of $35 \% \mathrm{H}_{2} \mathrm{O}_{2}$ that was quickly and completely absorbed. ${ }^{22}$ Dentin collagen also played an important role in increasing the cross-linking and stabilization of shear bond strength. Collagen in biological tissue is strengthened by the formation of native cross-links which provided the fibrillar resistance against enzymatic degradation as well as greater tensile properties. Inter molecular cross-linking is the prerequisite for stability, tensile strength and viscoelasticity of the collagen fibrils. The strengthening of collagen fibrils by cross-linking agents by increasing the mechanical properties and decreasing enzymatic degradation is a significant step in adhesive dentistry. ${ }^{23}$

The lowest value of shear bond strength was when dentin only being etched by $35 \%$ phosphoric acid (Group 1) and followed by bleached with 35\% $\mathrm{H}_{2} \mathrm{O}_{2}$ and application of 35\% phosphoric acid (Group 2). This showed that the application of $35 \% \mathrm{H}_{2} \mathrm{O}_{2}$ increased shear bond strength between dentin and composite resin. Even though the remnants of free radicals after bleaching process were still exist, it will compete with free radicals produced from polymerization of adhesive material. This further causes premature termination resulted in incomplete polymerization of the adhesive material. ${ }^{13,14}$ Low value of shear bond strength on Group 1 was possibly caused by the retention made from etching and bonding process on dentin. To achieve good bond strength on dentin, collagen is needed to make a hybrid layer of dentin to composite resin. Due to the in vitro nature of the study, the dentin samples were dehydrated and was lack of collagen.

\section{CONCLUSION}

The application of $10 \%$ ascorbic acid could improve the shear bond strength significantly in dentin treated with $35 \% \mathrm{H}_{2} \mathrm{O}_{2}$.

\section{REFERENCES}

1. Rahimi M, Jainaen A, Parashos P, Messer HH. Bonding of resin based sealers to root dentin. J Endod. 2009;35:121-4.

2. Dahl JE, Pallesen U. Tooth bleaching - A critical review of the biological aspects. Crit Rev Oral Biol Med. 2003;14:292-304.

3. Kim S, Yang ML. Aesthetic management of non-vital discolored teeth with internal bleaching. In: Tarnow DP, Chu SJ, Kim J. Aesthetic restorative dentistry: principles and practice. Montage Media; 2008. p.4-10.

4. Muraguchi K, Shigenobu S, Suzuki S, Tanaka T. Improvement of bonding tooth surfaces by ascorbic acid treatment. Dent Mater J. 2007;26:875-81.

5. Kaya AD, Turkun M. Reversal of dentin bonding to bleached teeth. Oper Dent. 2003;28;825-9.

6. Joiner A. Review of the effects of peroxide on enamel and dentine properties. J Dent. 2007;35:889-96.

7. Lobo V, Patil A, Phatak A, Chandra N. Free radicals, antioxidants and functional foods: Impact on human health. Pharmacogn Rev. 2010;4:118-26.

8. Halliwell B. Reactive species and antioxidants. Redox biology is a fundamental theme of aerobic life. Plant Physiol 2006;141:312-22.

9. Lipinski B. Hydroxyl radical and its scavengers in health and disease. Oxid Med Cell Longev. 2011;2011:809696.

10. Smith JJ, Cunningham CJ, Montgomery S. Cervical canal leakage after internal bleaching procedures. $\mathrm{J}$ Endod. 1992;18:476-81.

11. Attin T, Hannig C, Wiegand A, Attin R. Effect of bleaching on restorative materials and restorations - a systematic review. Dent Mater. 2004;20:852-61.

12. Lai SCN, Tay FR, Cheung GSP, Mak YF, Carvalho $\mathrm{RM}$, et al. Reversal of compromised bonding in bleached enamel. J Dent Res. 2002;81:477-81.

13. Teixeira ECN, Hara AT, Serra MC. Use of $37 \%$ carbamide peroxide in the walking bleach technique: a case report. Quintessence Int. 2004;35:97-102.

14. Vongphan N, Senawongse P, Somsiri W, Harnirattisai C. Effects of sodium ascorbate on microtensile bond 
strength of total-etching adhesive system to $\mathrm{NaOCl}$ treated dentine. J Dent. 2005;33:689-95.

15. Winarsi H. Antioksidan alami dan radikal bebas. Penerbit Kanisius, Yogyakarta, 2007;1-23,77-82,12247. Indonesian.

16. Bulut H, Kaya AD, Turkun M. Tensile bond strength of brackets after antioxidant treatment on bleached teeth. Eur J Orthod.2005;1-6.

17. Bouillaguet S. Biological risks of resin-Based materials to the dentin-pulp complex. Crit Rev Oral Biol Med.2004;15:47-60.

18. Bayne SC, Thompson JY, Taylor DF. Dental materials. In: Roberson TM, Heymann HO, Swift EJ. Sturdevant's art and science of operative dentistry. 4th ed. St.Louis: Mosby, 2002. p.194-5.

19. Weston $\mathrm{CH}$, Ito S, Wadgaonkar B, Pashley DH. Effects of time and concentration of sodium ascorbate on reversal of $\mathrm{NaOCl}$ - induced reduction in bond strengths. J Endod. 2007;33:879-81.

20. Roberson TM, Heymann HO, Ritter AV. Introduction to composite restorations. In :Sturdevant's art and science of operative dentistry. Ed: Roberson TM, Heymann HO, Swift EJ Jr. 5th ed. St Louis, Missouri:Mosby, 2002 :495-526.

21. Morris MD, Kwang-Won L, Agee K, Bouillaguet S, Pashley DH. Effect of sodium hypochlorite and RC prep on bond strengths of resin cement to endodontic surfaces. J Endod. 2001;27:753-7.

22. Fine AM. Oligomericproanthocyanidin complexes: history, structure, and phytopharmaceutical applications. Altern Med Rev. 2000;5:144-51.

23. Castellan CS, Pereira PN, Viana G, Chen SN, Pauli GF, Bedran-Russo AK. Solubility study of phytochemical cross-linking agents on dentin stiffness. J Dent. 2010;38:4316. 